\title{
Low Melting Property of Vanadate Tellurite Glass and its Characterization by IR Spectroscopy
}

\author{
Luo Shiyong ${ }^{a}$, Wang Ning ${ }^{b}$, Chen Meng ${ }^{a}$, Xu Wencai ${ }^{a}$ and Lv Yong \\ ${ }^{a}$ Laboratory of Printing \& Packaging Material and Technology-Beijing Area Major Laboratory, Beijing \\ Institute of Graphic Communication, Beijing, 102600, P R China \\ ${ }^{b}$ The Laboratory for study of Earth's interior and Geo fluids, Institute of Geochemistry, Chinese Academy of \\ Sciences, Guiyang, 550002, P R China
}

(Received November 20, 2008; final form November 26, 2008)

\begin{abstract}
Differential scanning calorimetry, X-ray diffraction, infrared spectra and fluidity evaluation experiments have been made for $(80-x) \mathrm{TeO}_{2} \mathrm{xV}_{2} \mathrm{O}_{5} \cdot 20 \mathrm{MO}(\mathrm{M}=\mathrm{Sn}$, $\mathrm{Bi}, \mathrm{Ca}, \mathrm{Na}$ and $\mathrm{K}$ ) glasses as potential replacement for lead( $\mathrm{PbO})$-based glass frits with low firing temperature. Glasses with $\mathrm{TeO}_{2}$ 0-44 mol\%, and $\mathrm{V}_{2} \mathrm{O}_{5} 39-82 \mathrm{~mol} \%$ were found unsuitable for glass frit since they were easy to crystallize. Glasses with the content of $\mathrm{TeO}_{2}$ 54-74 mol\% and $\mathrm{V}_{2} \mathrm{O}_{5} 9-29 \mathrm{~mol} \%$ indicate appropriate fluidity and do not crystallize in the re-melting process at 723$753 \mathrm{~K}$. The glass transition temperature of these glasses is at $544-578 \mathrm{~K}$. The glass structure is given by layer upon layer mainly connected by the structure units of $\left[\mathrm{VO}_{4}\right]$ and $\left[\mathrm{TeO}_{3}\right]$. Other modifier ions locate mainly between the layers. The isolated $\mathrm{V}=\mathrm{O}$ band from the $\mathrm{VO}_{5}$ bipyramids is not detected in the vitreous structure of the glasses presently investigated.
\end{abstract}

Keywords: Tellurite glass, Low glass transition temperature $\left(T_{\mathrm{g}}\right), 1 \mathrm{R}$ characterization

\section{INTRODUCTION}

Vanadate tellurite glasses are of both scientific and technical interest because of their low melting temperature, high refractive index, high dielectric constant and good infrared transmission. They are widely used in memory switching, electrical optical switching devices, solid state electrolytes /1-2/. There are various investigations focused on the structure and electrical, optical, and mechanic properties of various glass systems such as $\mathrm{TeO}_{2}-\mathrm{V}_{2} \mathrm{O}_{5} / 1-3 /, \mathrm{V}_{2} \mathrm{O}_{5}-\mathrm{P}_{2} \mathrm{O}_{5} / 4-5 /$, $\mathrm{Fe}_{2} \mathrm{O}_{3}-\mathrm{V}_{2} \mathrm{O}_{5} / 6 /, \mathrm{ZnO}-\mathrm{V}_{2} \mathrm{O}_{5} / 7 /, \mathrm{CdO}-\mathrm{V}_{2} \mathrm{O}_{5} / 7 /, \mathrm{Sb}_{2} \mathrm{O}_{3}-$ $\mathrm{V}_{2} \mathrm{O}_{5} / 7 /, \mathrm{R}_{2} \mathrm{O}-\mathrm{V}_{2} \mathrm{O}_{5}$ (where $\mathrm{R}$ is the alkali) /8/, PbO$\mathrm{V}_{2} \mathrm{O}_{5} / 9,10 /, \mathrm{Fe}_{2} \mathrm{O}_{3}-\mathrm{BaO}-\mathrm{V}_{2} \mathrm{O}_{5} / 11 /, \mathrm{Bi}_{2} \mathrm{O}_{3}-\mathrm{V}_{2} \mathrm{O}_{5} / 12 /$, $\mathrm{MgO}-\mathrm{V}_{2} \mathrm{O}_{5} / 13 /$, SrO- $\mathrm{V}_{2} \mathrm{O}_{5} / 14 /$, FeO-SrO- $\mathrm{V}_{2} \mathrm{O}_{5} / 15 /$, $\mathrm{Agl}-\mathrm{Ag}_{2} \mathrm{O}-\mathrm{V}_{2} \mathrm{O}_{5}-\mathrm{P}_{2} \mathrm{O}_{5} / 16 /, \quad \mathrm{CaO}-\mathrm{V}_{2} \mathrm{O}_{5} / 17 /, \mathrm{Bi}_{2} \mathrm{O}_{3}-$ $\mathrm{TeO}_{2}-\mathrm{V}_{2} \mathrm{O}_{5} / 18 /, \mathrm{Bi}_{2} \mathrm{O}_{3}-\mathrm{GeO}_{2}-\mathrm{V}_{2} \mathrm{O}_{5} / 19 /, \mathrm{B}_{2} \mathrm{O}_{3}-\mathrm{PbO}-$ $\mathrm{V}_{2} \mathrm{O}_{5} / 20 /, \mathrm{CuO}-\mathrm{V}_{2} \mathrm{O}_{5}-\mathrm{TeO}_{2} / 21 \%$. However, the low melting property of vanadate tellurite glass has not been extensively reported yet. Glass frits with low firing temperature are widely used as hermetic seal materials and adhesives in electrical pastes. Lead borosilicate glass with $\mathrm{PbO}$ typical more than $50 \mathrm{~mol} \%$ are widely used as seal materials or the binding agent of the electrical pastes $/ 22-24 /$. Recently, lead containing low melting glasses have been restricted because of its harmful effects on health and the environment. This prompts us to force the development of lead-free low melting glass. Generally, the firming temperature of lead-free glass frits is higher than that of lead contained glasses. Thus, it is very important to develop new lead free low melting glass for electrical components.

The main purpose of this paper is to examine vanadate tellurite based glasses of (80$\mathrm{x}) \mathrm{TeO}_{2} \cdot \mathrm{xV}_{2} \mathrm{O}_{5} \cdot 20 \mathrm{MO}(\mathrm{M}=\mathrm{Sn}, \mathrm{Bi}, \mathrm{Ca}, \mathrm{Na}$ and $\mathrm{K})$ as potential replacement for lead-based glass frits with 
firing temperature at $723-773 \mathrm{~K}$, to alternate lead contained in low melting glass for the lead free of electrical components. In this paper, vanadate tellurite based glasses were examined as potential replacements for $\mathrm{Pb}$-based glass frits with low firing temperature at 723-773 K. The glass samples were evaluated by glass transition temperature, and the fluidity during remelting process. The effects of chemical composition of the $\mathrm{V}_{2} \mathrm{O}_{5}-\mathrm{TeO}_{2}$ glass system on the low melting property and the structure of the vanadate tellurite glass were also analyzed by IR spectroscopy.

\section{EXPERIMENTAL}

Generally, $\mathrm{SnO}, \mathrm{Bi}_{2} \mathrm{O}_{3}, \mathrm{BaO}, \mathrm{Na}_{2} \mathrm{O}$ and $\mathrm{K}_{2} \mathrm{O}$ are widely used to develop low melting lead free glass. In the present investigation, about $20 \mathrm{~mol} \%$ of the $\mathrm{SnO}$, $\mathrm{Bi}_{2} \mathrm{O}_{3}, \mathrm{BaO}, \mathrm{Na}_{2} \mathrm{O}$ and $\mathrm{K}_{2} \mathrm{O}$ was added to decrease the firing temperature further. The chemical compositions of glass samples presently studied in mol\% are listed in
Table 1. Batches prepared by mixing of the chemically pure $\mathrm{V}_{2} \mathrm{O}_{5}, \mathrm{TeO}_{2}, \mathrm{Bi}_{2} \mathrm{O}_{3}, \mathrm{SnO}, \mathrm{BaCO}_{3}, \mathrm{Na}_{2} \mathrm{CO}_{3}$ and $\mathrm{K}_{2} \mathrm{CO}_{3}$ were melted in an alumina crucible at temperature about $1223 \mathrm{~K}$ for 60 minutes; then the glass melts were quenched to room temperature by pouring the liquids on to a brass plate and immediately pressed by another brass plate. Samples were in the form of powders with the size from 1 to 30 microns.

The differential scanning calorimetry (DSC) measurements of the samples were performed in a differential scanning calorimeter (DSC-200PC) with a heating rate of $10 \mathrm{~K} / \mathrm{min}$ in the temperature from 293 to $853 \mathrm{~K}$, the flow rate of nitrogen gas was $10 \mathrm{~mL} / \mathrm{min}$. The infrared spectroscopy (IR) spectra at room temperature of the powdered glass samples in the $\mathrm{KBr}$ matrix were recorded with a spectrometer (FTIR-8400 SHIMADZU) in the wave number range from $4 \times 10^{4}$ to $4 \times 10^{6} \mathrm{~m}^{-1}\left(400\right.$ to $\left.4000 \mathrm{~cm}^{-1}\right)$. The amorphous nature of samples was checked by X-ray diffraction (D/Max2200 RIGAKU).

Table 1

Chemical compositions of the studied glasses in mol\%

\begin{tabular}{|l|l|l|l|l|l|l|l|}
\hline Glass No. & $\mathrm{TeO}_{2}$ & $\mathrm{~V}_{2} \mathrm{O}_{5}$ & $\mathrm{Bi}_{2} \mathrm{O}_{3}$ & $\mathrm{SnO}_{2}$ & $\mathrm{BaO}$ & $\mathrm{Na}_{2} \mathrm{O}$ & $\mathrm{K}_{2} \mathrm{O}$ \\
\hline $\mathrm{S} 1$ & 44.09 & 38.80 & 4.23 & 3.53 & 4.59 & 2.82 & 1.94 \\
\hline $\mathrm{S} 2$ & 33.56 & 49.10 & 4.29 & 3.57 & 4.65 & 2.86 & 1.97 \\
\hline S3 & 22.66 & 59.76 & 4.35 & 3.63 & 4.71 & 2.90 & 1.99 \\
\hline S4 & 11.48 & 70.69 & 4.41 & 3.68 & 4.78 & 2.94 & 2.02 \\
\hline S5 & 0 & 81.92 & 4.47 & 3.73 & 4.85 & 2.98 & 2.05 \\
\hline S6 & 54.40 & 28.70 & 4.18 & 3.48 & 4.53 & 2.79 & 1.92 \\
\hline S7 & 64.46 & 18.87 & 4.12 & 3.44 & 4.47 & 2.75 & 1.89 \\
\hline S8 & 74.23 & 9.31 & 4.07 & 3.39 & 4.41 & 2.71 & 1.88 \\
\hline S9 & 83.75 & 0 & 4.02 & 3.35 & 4.36 & 2.68 & 1.84 \\
\hline
\end{tabular}

\section{RESULTS AND DISCUSSION}

\subsection{The low melting property of vanadate tellurite glasses}

The DSC curves of all samples were divided into two classes by the nature of crystallization and noncrystallization after the DSC measurements. The curve consists of an endothermic peak due to a glass transition and an exothermic peak due to crystallization. Figure 1 shows glass samples of $\mathrm{S6}, \mathrm{S7}, \mathrm{S} 8$ and $\mathrm{S9}$, with the content of $\mathrm{TeO}_{2} 54-83 \mathrm{~mol} \%$, and $\mathrm{V}_{2} \mathrm{O}_{5} \quad 0-29 \mathrm{~mol} \%$. These glass samples were not found to be crystallized after the DSC measurements. The glass transition temperature, $\mathrm{Tg}$, of theses samples of $\mathrm{S} 6, \mathrm{~S} 7, \mathrm{~S} 8$ and $\mathrm{S} 9$ was $550,554,578$ and $613 \mathrm{~K}$, respectively. The $7 \mathrm{~g}$ value of these glass samples increases with the 
increasing of $\mathrm{TeO}_{2}$ content. On the other hand, glass samples denoted by $\mathrm{SI}, \mathrm{S} 2 \mathrm{~S} 3$ S4and $\mathrm{S} 5$ with the content of $\mathrm{TeO}_{2} \quad 0-44 \mathrm{~mol} \%$, and $\mathrm{V}_{2} \mathrm{O}_{5} \quad 39-82 \mathrm{~mol} \%$ were crystallized after the DSC measurements, as shown in Figure 2. The crystallization temperature was found to be in the range from 513 to $563 \mathrm{~K}$, depending on the composition. For this reason, further attention focuses only on S6, S7, S8 and S9.

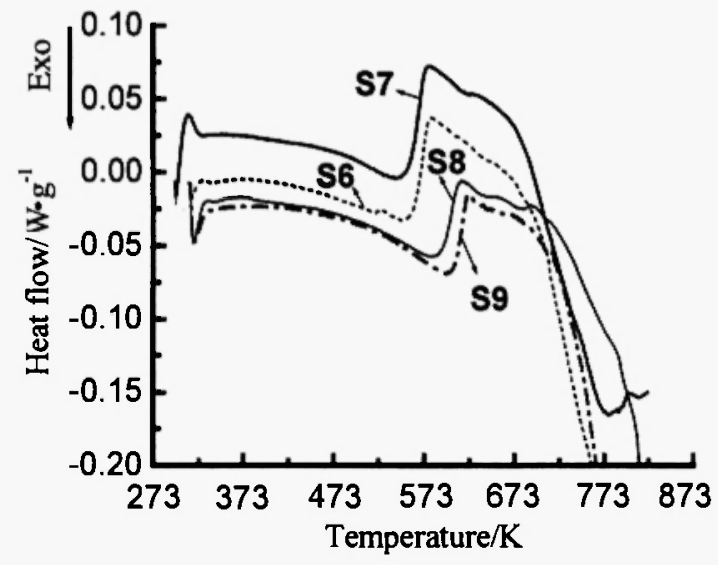

Fig. 1: DSC curves of the glass samples without crystallization.

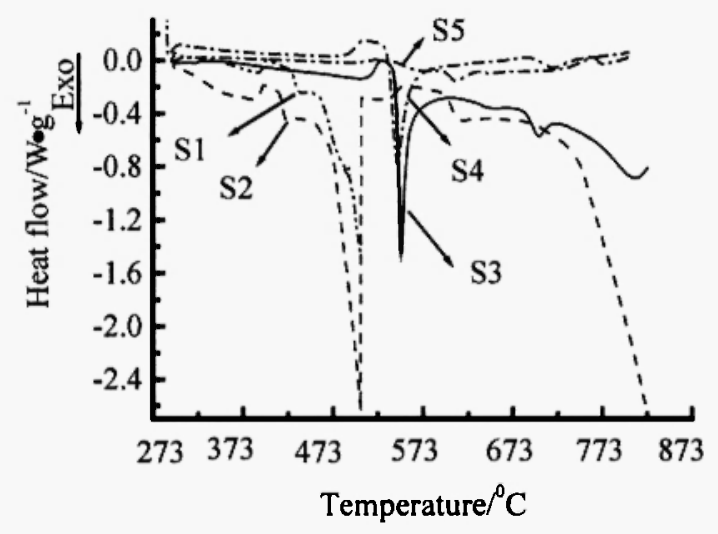

Fig. 2: DSC curves of the glass samples with crystallization.

Figure 3 shows XRD pattern of as quenched glass samples of S6, S7, S8 and S9 together with that of S5, for comparison. The S5 sample clearly shows the crystalline nature and it is attributed to the contained $\mathrm{V}_{2} \mathrm{O}_{5}$ crystalline. The "other samples" in Figure 3 means XRD patterns of S6, S7, S8 and S9 samples showing similar feature of no discrete sharp peaks. This confirms that the structure of S6, S7, S8 and S9 samples is characterized by the so-called amorphous network where the $\mathrm{V}_{2} \mathrm{O}_{5}$ component is completely contained in the glass matrix.

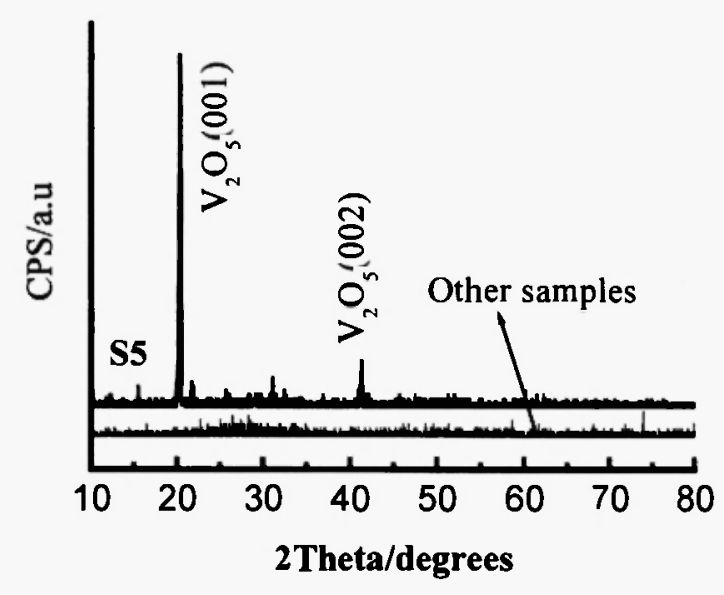

Fig. 3: X-ray diffraction patterns of as quenched glass samples.

\subsection{The fluidity evaluation of the vanadate tellurite glasses at re-melting process}

The purpose of the present work is to develop a new glass system as potential replacement for lead-based glass frits with low firing temperature at $723-773 \mathrm{~K}$. As the hermetic seal glasses or the binders for electrical pastes, the application form of the low firing glass is required as powders with size of $1-30$ microns. It is an important property of the low firing glass frit that the glass powder possesses proper fluidity at the seal temperature or at the firing temperature. The fluidity was usually evaluated by an experimental result of so called "button diameter", which was originated from Owens Corning and then modified by the China Industry Standard of SJ3232.3-1989 /25/. The main points of this "button diameter" experiment are: first, an appropriate amount of glass powder, depending on the density of the glass, is pressed by a pressure of $5 \mathrm{Mpa}$ in a steel mould to form a $5 \mathrm{~mm}$ high powder column with a diameter of $12 \mathrm{~mm}$. Second, the powder column is placed on a plate glass and then heated according to a specified temperature schedule, fired at a proper peak 
temperature for 10 minutes in an electrical furnace. Finally, the diameter of the fired glass matrix is determined and is used to evaluate the fluidity of the low melting glass. The diameter of the glass matrix after fired at a peak temperature for 10 minutes is generally within the range from 24 to $27 \mathrm{~mm}$ and this peak temperature would be appropriate to be taken as the seal temperature for applying the low melting glass to seal glass or paste for the thick film of some electrical parts.

In the present investigation, for each glass sample listed in Table 1, 5.00 grams glass powder was pressed by a pressure of $5 \mathrm{Mpa}$ in a steel mould to form a $\sim 5 \mathrm{~mm}$ high powder column with a diameter of $12 \mathrm{~mm}$, placed it on a plate glass, then fired in an electrical furnace. The temperature schedule is as follows. The heating rate is $10 \mathrm{~K} / \mathrm{min}$ from room temperature to $673 \mathrm{~K}, 5 \mathrm{~K} / \mathrm{min}$ from 673 to $723 \mathrm{~K}$, and keeping at the peak temperature of $723 \mathrm{~K}$ for 10 minutes, then cooled to room temperature. The button diameter results are given in Table 2.

Table 2

The button diameter results of the samples after fired at $723 \mathrm{~K}$ for 10 minutes

\begin{tabular}{|c|c|c|c|}
\hline Glass & $T_{\mathrm{g}} /$ & Button & Visual phenomena of the \\
\hline No. & $\mathbf{K}$ & $\begin{array}{c}\text { diameter / } \\
\mathrm{mm}\end{array}$ & button matrix \\
\hline SI & & 18.5 & $\begin{array}{l}\text { Crystallized, no glass } \\
\text { gloss on the surface }\end{array}$ \\
\hline S2 & & 18.0 & $\begin{array}{l}\text { Crystallized, no glass } \\
\text { gloss on the surface }\end{array}$ \\
\hline S3 & & 17.3 & $\begin{array}{l}\text { Crystallized, no glass } \\
\text { gloss on the surface }\end{array}$ \\
\hline S4 & & 15.5 & $\begin{array}{l}\text { Crystallized, no glass } \\
\text { gloss on the surface }\end{array}$ \\
\hline S5 & & 13.2 & $\begin{array}{l}\text { Crystallized, no glass } \\
\text { gloss on the surface }\end{array}$ \\
\hline S6 & 550 & 27.3 & $\begin{array}{l}\text { Non-crystalline, has } \\
\text { good glass gloss }\end{array}$ \\
\hline S7 & 554 & 26.5 & $\begin{array}{l}\text { Non-crystalline, has } \\
\text { good glass gloss }\end{array}$ \\
\hline S8 & 578 & 23.1 & $\begin{array}{l}\text { Non-crystalline, has } \\
\text { good glass gloss }\end{array}$ \\
\hline S9 & 613 & 20.1 & $\begin{array}{l}\text { Non-crystalline, has } \\
\text { good glass gloss }\end{array}$ \\
\hline
\end{tabular}

When the peak temperature was kept at $743 \mathrm{~K}$, the button diameter of S8 was about $25 \mathrm{~mm}$. The visual crystallization phenomena of the button matrix, listed in Table 2, were in agreement with those of the DSC measurements. On the basis of the fluidity and crystallization, the glass samples of S6, S7 and S8 were found to be proper for seal glass frit or the adhesive of electrical paste with the firing temperature at $723-773 \mathrm{~K}$.

\subsection{Characterization by IR spectroscopy of vanadium tellurite glasses}

Samples of S1, S2, S3, S4 and S5, shown in Table 1, with $\mathrm{TeO}_{2}$ 0-44 mol\%, $\mathrm{V}_{2} \mathrm{O}_{5} \quad 39-82 \mathrm{~mol} \%$ were crystallized and good flow could not be obtained during re-melting process at $723-773 \mathrm{~K}$. For these reasons, these samples are not qualified for the use of low firing seal glass frit and adhesive of electrical paste. Then, their structure was also not discussed further.

The experimental IR spectra for samples of S6, S7, S8 and $\mathrm{S} 9$ with $\mathrm{TeO}_{2} 54-84 \mathrm{~mol} \%, \mathrm{~V}_{2} \mathrm{O}_{5}$ 0-30 mol\% are given in Figure 4. For comparison, the spectra of pure $\mathrm{TeO}_{2}$ and $\mathrm{V}_{2} \mathrm{O}_{5}$ oxides, as well as sample $\mathrm{S} 5$ were also given in Figure 4. Except for S5, four glass samples show the spectra with a broad absorption band from $5.6 \times 10^{4}$ to $1.0 \times 10^{5} \mathrm{~m}^{-1}$ ( 560 to $\left.1000 \mathrm{~cm}^{-1}\right)$.

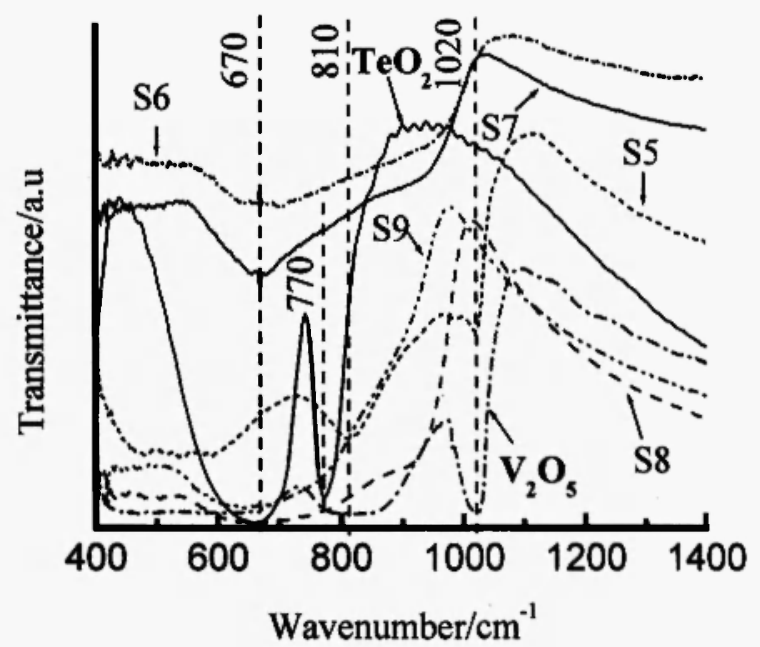

Fig. 4: Infrared spectra of the glass samples and pure oxides 
The absorption band at about $640 \mathrm{~cm}^{-1}$ of pure $\mathrm{TeO}_{2}$ was attributed to $\mathrm{TeO}_{4}$ tetragonal pyramids. It was reported that this band shifted from $640 \mathrm{~cm}^{-1}$ to $680 \mathrm{~cm}^{-1}$ on adding other metal oxides/3/. Dimitriv et al/26/ report that the IR absorption band in the range from $620-680 \mathrm{~cm}^{-1}$ can be attributed to $\mathrm{TeO}_{3}$ trigonal pyramids. These bands were observed in the IR spectra of the present $\mathrm{TeO}_{2}-\mathrm{V}_{2} \mathrm{O}_{5}$ glass samples of $\mathrm{S} 6, \mathrm{~S} 7, \mathrm{~S} 8$ and $\mathrm{S} 9 . \mathrm{Te}$ in the glass structure is suggested mainly in the form of $\mathrm{TeO}_{3}$ trigonal pyramids. With increasing $\mathrm{TeO}_{2}$ content from 40 to $80 \mathrm{~mol} \%$, the glass structure gradually changes from the continuous vanadate network to the continuous tellurite network. The formation of $\mathrm{TeO}_{3}$ trigonal pyramids leads to the reduction of the glass rigidity related to both the increase in ring size and decrease in melting temperature. Sidkey et al. $12 /$ conclude from the structural study of $\left(\mathrm{TeO}_{2}\right)_{1-\mathrm{x}}-\left(\mathrm{V}_{2} \mathrm{O}_{5}\right)_{\mathbf{x}}$ by ultrasonic study that vanadium tellurite glasses containing more than $80 \mathrm{~mol}^{2} \mathrm{TeO}_{2}$ have a continuous tellurite network which contains four-coordinated $\mathrm{Te}$. One can infer that the network of the samples of S9, with $84 \mathrm{~mol} \%$ of $\mathrm{TeO}_{2}$, is mainly connected by four-coordinated $\mathrm{Te}$. The results of DSC analysis and fluidity evaluation for S9 sample indicate difficulty to crystallize during remelting process. However, it is not suitable for low melting glass since its glass transition temperature is up to $613 \mathrm{~K}$. For samples of $\mathrm{S} 6, \mathrm{~S} 7$ and $\mathrm{S} 8, \mathrm{Te}$ in the glass structure is characterized mainly by the form of $\mathrm{TeO}_{3}$ trigonal pyramids.

The IR band at $\sim 1020 \mathrm{~cm}^{-1}$ of pure crystalline $\mathrm{V}_{2} \mathrm{O}_{5}$ is characteristic of the isolated $\mathrm{V}=\mathrm{O}$ vanadyl groups in $\mathrm{VO}_{5}$ trigonal bi-pyramids. The bands at $\sim 830$ and $\sim 620$ $\mathrm{cm}^{-1}$ are due to the symmetric and antisymmetric vibration modes of the V-O-V group and the band at $\sim 480 \mathrm{~cm}^{1}$ is attributed to the angular deformation vibration of the $\mathrm{O}-\mathrm{V}$ bond. The band at $\sim 1020 \mathrm{~cm}^{-1}$ due to $\mathrm{V}=\mathrm{O}$ only appeared in the spectrum of the glass sample S5, but it was not observed in the samples of S6, $\mathrm{S7}, \mathrm{S} 8$ and $\mathrm{S} 9$. The isolated $\mathrm{V}=\mathrm{O}$ bond from the $\mathrm{VO}_{5}$ trigonal bipyramids was not found in the vitreous structure of the present glass samples. This was quite different from early reports $/ 2,7 /$ that the $\mathrm{V}=\mathrm{O}$ band occurred in the structure of amorphous vanadate tellurite glass. The difference might be due to the different conditions of glass preparation (melting temperature, duration melting, etc). The absorption band of V-O-V at $\sim 830 \mathrm{~cm}^{-1}$ is not clearly for the broad bands from 560 to $1000 \mathrm{~cm}^{-1}$. One can infer that the $\mathrm{V}$ ion is octahedrally coordinated.

$\mathrm{V}_{2} \mathrm{O}_{5}$ and $\mathrm{TeO}_{2}$ are known to be typical conditional glass formers. The IR spectra of samples of $S 6, S 7$ and S8 show that $\mathrm{Te}$ in the glass structure is mainly three coordinated and the $\mathrm{V}$ is octahedrally coordinated. The structure of the vanadate tellurite glass, with low melting property, $\mathrm{TeO}_{2} 54-74 \mathrm{~mol} \%, \mathrm{~V}_{2} \mathrm{O}_{5} 9-29 \mathrm{~mol} \%$, may be attributed to the layer structure formed by distorted $\mathrm{TeO}_{3}$ trigonal pyramids and $\mathrm{VO}_{4}$ octahedra sharing edges and corners.

The addition of network modifier metal oxides such as $\mathrm{Bi}_{2} \mathrm{O}_{3}, \mathrm{SnO}, \mathrm{BaO}, \mathrm{Na}_{2} \mathrm{O}$ and $\mathrm{K}_{2} \mathrm{O}$, would make the glass network loose. In the first case, network modifier ions are mainly located between the vanadate or tellurite chains. They can interact directly with the isolated V-O and $\mathrm{Te}-\mathrm{O}$ bonds and distort the $\mathrm{TeO}_{3}$ trigonal pyramids and $\mathrm{VO}_{4}$ octahedra further. In the second case, a few ions with strong energy may occupy positions in the chain itself, where some of the weaker V-O-V and Te$\mathrm{O}-\mathrm{Te}$ bonds break and they form new $\mathrm{V}-\mathrm{O}$-ions bridges. Thus, the glass transition temperature of glasses decreases further.

\section{CONCLUSIONS}

The structure and low melting property of $(80-\mathrm{x}) \mathrm{TeO}_{2} \cdot \mathrm{xV}_{2} \mathrm{O}_{5} \cdot 20 \mathrm{MO}(\mathrm{M}=\mathrm{Sn}, \mathrm{Bi}, \mathrm{Ca}, \mathrm{Na}$ and $\mathrm{K})$ glasses have been investigated. Glasses with $\mathrm{TeO}_{2}$ 0-44 $\mathrm{mol} \%$, and $\mathrm{V}_{2} \mathrm{O}_{5} 39-82 \mathrm{~mol} \%$ are not suitable for glass frit since they are easy to crystallize. The glasses with the content of $\mathrm{TeO}_{2}$ 54-74 mol\%, and $\mathrm{V}_{2} \mathrm{O}_{5} 9-29 \mathrm{~mol} \%$ possess appropriate fluidity and do not crystallize in the re-melting process at the temperature range from 723 to $773 \mathrm{~K}$. The glass transition temperature of these glasses is in the temperature range from 544 to $578 \mathrm{~K}$. The structure of glasses with the content of $\mathrm{TeO}_{2}$ 54-74 $\mathrm{mol} \%$, and $\mathrm{V}_{2} \mathrm{O}_{5} 9-29 \mathrm{~mol} \%$ is layer upon layer structure mainly connected by $\mathrm{VO}_{4}$ tetrahedra and $\mathrm{TeO}_{3}$ trigonal pyramids. Other modifier ions such as $\mathrm{Sn}^{2+}$ $\mathrm{Bi}^{3+}, \mathrm{Ba}^{2+}, \mathrm{Na}^{+}$and $\mathrm{K}^{+}$locate mainly between the layers 
and they contribute to the decrease in glass transition temperature. The isolated $\mathrm{V}=\mathrm{O}$ band from the $\mathrm{VO}_{5}$ bipyramids is not detected in the vitreous structure of the glasses. As a result, vanadate tellurite glasses may be a potential candidate for use as a lead-free composition glass frit with low firing temperature.

\section{ACKNOWLEDGEMENTS}

The authors thankfully acknowledge the geherous financial support provided by the Science and Technology Program of Beijing Municipal Commission of Education, and by the Science and Technology Research Funding Project of Beijing Institute of Graphic Communication, and by the Funding Project for Academic Human Resource Development in Institutions of Higher Learning Under The Jurisdiction of Beijing Municipal (PHR IHLB)

\section{REFERENCES}

1. D. Bersani, G. Antonioli, P. P. Lottici, Y. Dimitriev, V. Dimitrov and P. Kobourova, J. NonCryst. Solids, 232/234, 293-299 (1998).

2. M.A .Sidkey, R EI Mallawany, R I Nakhla and A. Abd EI-Moneim, J. Non-Cryst. Solids, 215, 75-82 (1997)

3. A. Abd El-Moneim, Mater. Chem. Phys., 73, 318 322 (2002)

4. F.M. Ezz-Eldin, Nucl. Instrum. Meth. B, 1599, 166-175 (1999)

5. J.E. Garbarczyk, P. Jozwiak, M. Wasiucionek and J.L. Nowinski, J. Power Sources, 173, 743-747 (2007)

6. S. Mandal, S. Hazra, D. Das and A. Ghosh, J. NonCryst. Solids, 183, 315-319 (1995)

7. V. Dimitrov, J. Non-Cryst. Solids, 192/193, 183. 186 (1995)

8. J.M. Lewis, C.P.O Brien, M. Affatigato and S.A Feller, J. Non-Cryst. Solids, 293/295, 663-668 (2001)

9. S. Hayakawa, T. Yoko and S. Sakka, J. Non-Cryst. Solids 183, 73-84 (1995)
10. K.V. Ramesh and D.L. Sastry, Physica B, 387, 4551 (2007)

11. E. Mansour, Y.M. Moustafa, G.M. EI-Damrawi, S. Abd EI-Maksoud and $\mathrm{H}$ Doweidar, Physica $B$, 305, 242-249 (2001)

12. S. Chakraborty, M. Sadhukhan, B. K. Chaudhuri, H. Mori and H. Sakata, Mater. Chem. Phys., 50, 219-226 (1997)

13. S. Sen and A. Ghosh, J. Non-Cryst. Solids 258, 2933 (1999)

14. G. D. Khattak and N. Tabet, J. Electron Spectrosc. Relat. Phenom., 136, 257-264 (2004)

15. M. S. Aziz, F. Abdel-Wahab, A. G. Mostafa and E. M. EI-Agwany, Mater. Chem. Phys., 91, 532-537 (2005)

16. P.Machowski, M. Opallo, J. E. Garbarczyk and M. Wasiucionek, Solid. State Ionics, 157, 287-291 (2003)

17. N.Tashtoush, A.M. Qudah and M.M. El-Desoky, $J$. Non-Cryst. Solids, 68, 1926-1932 (2007)

18. V. Rajendran, N. Palanivelu, B. K. Chaudhuri and K. Goswami, J. Non-Cryst. Solids, 320, 195-209 (2003)

19. V.Dimitrov, Y.Dimitriev and A.Montenero, $J$. Non-Cryst. Solids, 180, 51-57 (1994)

20. C. N.Reddy, V.C.Veeranna Gowda and R.P. Sreekanth Chakradhar, J. Non-Cryst. Solids, 354, 32-40 (2008)

21. M. M. EI-Desoky and M. S. AI-Assiri, Mater. Sci. Eng. $B, 137,237-246$ (2007)

22. S.A. Ketkar, G.G. Umarji, G.J. Phatak, J.D. Ambekar, I.C. Rao, U.P. Mulik and D.P. Amalnerkar, Mater. Sci. Eng. B, 132, 215-221 (2006)

23. Joon-Young Song and Se-Young Choi, Displays, 27, 112-116 (2006)

24. R. Morena, J. Non-Cryst. Solids, 263/264, 382-387 (2000)

25. China Industry Standard of SJ3232.3-1989. Method for measurement of flowability of glass powder for soldering with low-melt point.

26. Y. Dimitriv, V. Dimitrov, M. Arnaudov and D. Topalov, J. Non-Cryst. Solids, 57, 147-151 (1983) 